\title{
Regulation of Salmonella typhimurium pyr Gene Expression: Effect of Changing Both Purine and Pyrimidine Nucleotide Pools
}

\author{
By KAJ FRANK JENSEN \\ Enzyme Division, Institute of Biological Chemistry, Solvgade 83, DK-1307 Copenhagen K, \\ Denmark
}

(Received 29 September 1988; revised 26 December 1988; accepted 4 January 1989)

\begin{abstract}
The synthesis of the pyrimidine biosynthetic enzymes is repressed by the pyrimidine nucleotide end-products of the pathway. However, purine nucleotides also play a role. In this study, I have measured expression of the pyr genes $(p y r A-E)$ in Salmonella typhimurium strains harbouring mutations that permit manipulation of the intracellular pools of both pyrimidine and purine nucleotides. The results identify the effectory purine compound as being a guanine nucleotide; it is probably GTP, but it may be GDP or GMP. The synthesis of carbamoylphosphate synthase, encoded by $p y r A$, and particularly dihydroorotase, encoded by $\operatorname{pyr} C$, and dihydroorotate dehydrogenase, encoded by $p y r D$, is stimulated by the guanine nucleotide, while the synthesis of aspartate transcarbamoylase, encoded by $p y r B I$, and orotate phosphoribosyltransferase, encoded by pyrE, is inhibited by guanine nucleotides. The regulatory pattern of each pyr gene is discussed in relation to present knowledge on gene structure and regulatory mechanism.
\end{abstract}

\section{INTRODUCTION}

The biosynthesis of UMP is catalysed by six enzymes (Fig. 1) encoded by the genes $\operatorname{pyr} A-F$, which are unlinked on the chromosome of Salmonella typhimurium. The synthesis of these enzymes is under repressive control by pyrimidine compounds, but the levels of the different enzymes do not change in parallel. Schwartz \& Neuhard (1975) suggested that the cellular concentration of CTP regulated the levels of dihydroorotase $(\mathrm{pyrC})$ and dihydroorotate dehydrogenase $(p y r D)$ while the cellular concentration of UTP regulated the synthesis of aspartate transcarbamoylase ( $p y r B I)$, orotate phosphoribosyltransferase ( $p y r E)$ and OMP decarboxylase $(p y r F)$. However, Kelln et al. (1975) were unable to find any clear correlations between the level of the individual enzyme and the absolute concentration of any individual pyrimidine nucleoside triphosphate. Thus, these authors suggested that pool ratios rather than the concentrations of individual compounds might regulate pyr gene expression.

In a selection for mutants resistant to the toxic pyrimidine analogues 5-fluorouracil and 5fluorouridine, a mutant with a leaky requirement for guanine was obtained. The mutation responsible ( $g u a B 235$ ) caused the formation of a defective GMP synthase (Jensen, 1979). In the absence of guanine supplement the mutant grew exponentially, but slowly. At the same time it contained a perturbed pattern of purine nucleotide pools relative to the parental strain: the pool of GTP was reduced fivefold, the ATP pool was twice normal, the CTP pool was twofold reduced, while the UTP pool was slightly above normal. Furthermore, the levels of pyrimidine biosynthetic enzymes in the guaB235 mutant were abnormal relative to the results of previous studies (Schwartz \& Neuhard, 1975), since $p y r C$ and $p y r D$ gene expression was tenfold reduced while the expression of $p y r B I, p y r E$ and $p y r F$ was considerably elevated (Jensen, 1979). These observatios indicated that purine nucleotides play an important role in regulating $S$. typhimurium pyr gene expression. Here, I have characterized the effect of purine nucleotides on pyr gene expression in more detail. 
Table 1. S. typhimurium strains used

Strain

KP1001

KP1294

KP1469

KP1470

KP1474

KP1476

KP1478

KP1479

KP1482

KP1489

KP1535

KP1548

KP1722

KP1723

KP1724

KP1725
Genotype

Salmonella typhimurium LT2

guaC 234

cdd-9 cod-8 deoD201 udp-11

cdd-9 cod-8 deoD201 udp-11 guaB235(leaky)

metB406 guaB235

cdd-9 cod-8 deoD201 udp-11 guaC236(ts)

zag-207:: $\operatorname{Tn} 10$

purE1522 pyrH1631

purE1522 pyrH1631 zag-207:: Tn 10

cdd-9 cod-8 deoD201 udp-11 guaA

purE1522

purE1522 deoD203

cdd-9 cod-8 deoD201 udp-11 guaB235 zag-207::Tn10

cdd-9 cod-8 deoD201 udp-11 guaB235 pyrH1631 zag-207:: Tn10

cdd-9 cod-8 deoD201 udp-11 zag-207:: Tn 10

cdd-9 cod-8 deoD201 udp-11 pyrH1631 zag-207:: Tn10
Source or reference

J. L. Ingraham

Hoffmeyer \& Neuhard (1971)

Jensen (1979)

Jensen (1979)

Own collection

Jensen (1979)

Own collection

Neuhard et al. (1982)

Hoffmeyer \& Neuhard (1971)

Hoffmeyer \& Neuhard (1971)

\section{METHODS}

Strains used. The strains used are all derivatives of Salmonella typhimurium LT2 and are given in Table 1. Strain KP1479 was selected in strain KP1 535 by selecting for the ability to use 2,6-diaminopurine $\left(200 \mu \mathrm{g} \mathrm{ml}^{-1}\right)$ as purine source on minimal agar plates. For unknown reasons approximately one-third of all clones in this type of selection are altered in UMP kinase (K. F. Jensen \& P. Nygaard, unpublished results). The $p y r H$ mutation of KP1479 was transduced into KP1470 (via KP1482) by using phage P22 and selecting for resistance to tetracycline $\left(10 \mu \mathrm{g} \mathrm{ml}^{-1}\right)$ on agar plates containing glucose $(0.2 \%)$, Casamino acids $(0.2 \%)$, guanine $\left(30 \mu \mathrm{g} \mathrm{ml}^{-1}\right)$ and thiamin $\left(1 \mu \mathrm{g} \mathrm{ml}^{-1}\right)$. This resulted in formation of KP1722 and KP1723. KP1724 and KP1725 were made by a similar transduction using KP1469 as recipient.

Cell growth and media. Liquid cultures were grown at $37^{\circ} \mathrm{C}$ in the Tris-buffered medium of Edlin \& Maaløe (1966) with the phosphate concentration reduced to $0.3 \mathrm{mM}$. The medium was supplemented with glucose $(0.2 \%)$ and thiamin $\left(1 \mu \mathrm{g} \mathrm{m}^{-1}\right)$ as well as amino acids, purines and pyrimidines as indicated. Solid media contained $1.5 \%$ (w/v) Difco agar and were based on the phosphate-buffered medium of Clark \& Maaløe (1967) or L-broth (Miller, 1972). Transductions using phage P22HT/int-201 were done as described previously (Neuhard et al., 1982).

Determination of nucleoside triphosphate pools. [ $\left.{ }^{32} \mathrm{P}\right] \mathrm{Orthophosphate}(25 \mu \mathrm{Ci})$ was added to $2 \mathrm{ml}$ exponentially growing culture at $\mathrm{OD}_{436}=0 \cdot 2$. Growth was continued to $\mathrm{OD}_{436}=0 \cdot 8$. Then the cells were extracted by pipetting $0.5 \mathrm{ml}$ culture into $0.1 \mathrm{ml} 2 \mathrm{M}$-formic acid. Cell debris was removed by centrifugation after 30 min incubation in a melting icebath. The content of nucleoside triphosphates was determined by two-dimensional chromatography on polyethyleneimine-impregnated cellulose thin-layer plates on plastic sheets as described by Jensen et al. (1979).

Determination of pyrimidine biosynthetic enzymes. The cells were harvested in the exponential phase at $\mathrm{OD}_{436}=0.8$. For determination of carbamoylphosphate synthase activity by the procedure of Abdelal \& Ingraham (1975) the cells were resuspended in $0 \cdot 1 \mathrm{M}$-potassium phosphate $\mathrm{pH} 7 \cdot 1$ and disrupted by ultrasonic treatment. For determination of the other enzymes the cells were suspended and disrupted in $0.1 \mathrm{M}-\mathrm{Tris} / \mathrm{HCl}$ pH 7.5, 2 mM-EDTA. Aspartate transcarbamoylase activities were determined by the colorimetric procedure of Gerhart \& Pardee (1962). Dihydroorotase and dihydroorotate dehydrogenase activities were measured as described by Schwartz \& Neuhard (1975), while the activity of orotate phosphoribosyltransferase was measured according to Poulsen et al. (1983). As a control the activity of glucose-6-phosphate dehydrogenase was assayed according to Kornberg \& Horecker (1955).

One enzyme unit is defined as the amount of enzyme that converts $1 \mathrm{nmol}$ substrate to product $\mathrm{min}^{-1}$.

Protein concentrations were determined by the Lowry method.

\section{RESULTS AND DISCUSSION}

\section{Effects of purine nucleotides on pyr gene expression}

I wanted to test if the levels of pyrimidine nucleotide biosynthetic enzymes characteristic for the guaB235 mutant could be reproduced by other means of manipulating the purine nucleotide pools. Thus, a sample of mutants with other defects in purine nucleotide biosynthesis or interconversion (Table 1) were analysed for content of nucleoside triphosphates and pyrimidine biosynthetic enzymes (see Table 2). The two strains KP1535 and KP1548 require purines due to 


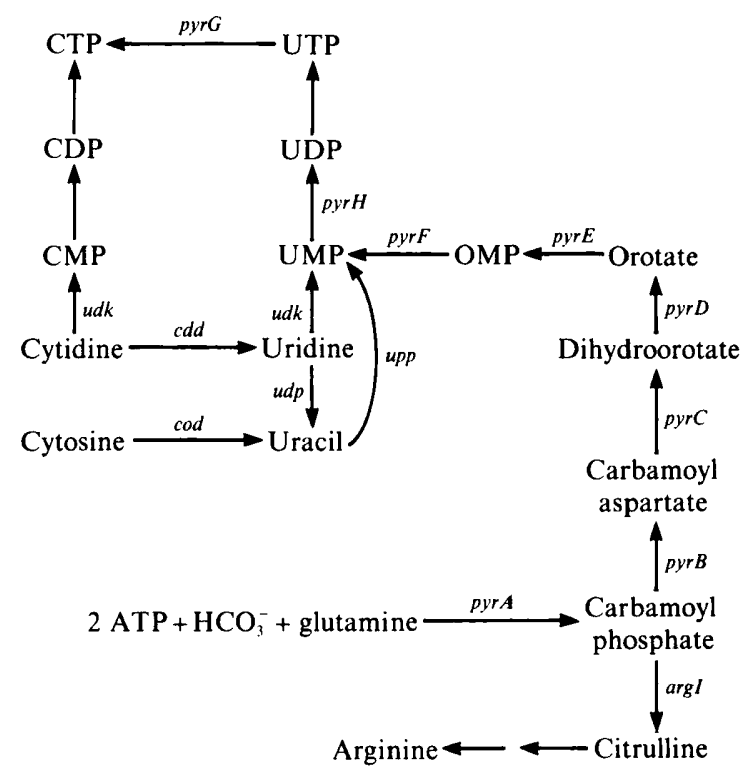

Fig. 1. Pathways for the biosynthesis and interconversion of pyrimidine nucleotides in S. typhimurium. The enzymes are identified by their corresponding gene designations as follows: argI, ornithine transcarbamoylase (EC 2.1.3.3); cdd, cytidine deaminase (EC 3.5.4.5); cod, cytosine deaminase (3.5.4 .1); pyrA, carbamoyl-phosphate synthase (EC 6.3.5.5); pyrB, aspartate transcarbamoylase (EC 2.1.3.2); pyrC, dihydroorotase (EC 3.5.2.3); pyrD, dihydroorotate dehydrogenase (EC 1.3.3.1); pyrE, orotate phosphoribosyltransferase (EC 2.4.2.10); pyrF, orotidine 5'-phosphate (OMP) decarboxylase (EC 4.1.1.23); pyrG, CTP synthase (EC 6.3.4.2); pyrH, UMP kinase (EC 2.7.4.14); $u d k$, uridine kinase (EC 2.7.1.48); udp, uridine phosphorylase (EC 2.4.2.3); upp, uracil phosphoribosyltransferase (EC 2.4.2.9).

mutations in purE (see Fig. 2). This requirement can be satisfied by adenine, hypoxanthine or gasnine. However, the strains contain widely different pools of purine nucleotides depending on the added purine. Following growth on adenine the cells contained high pools of adenine nucleotides (exemplified by ATP) and low pools of guanine nucleotides (exemplified by GTP). The nucleotide pools were more perturbed from the wild-type (KP1001) pattern with KP1548 than with KP1535. This is because KP1548 carries a deoD mutation that destroys one of two pathways for the conversion of adenine nucleotides to guanine nucleotides (see Fig. 2, and Hoffmeyer \& Neuhard, 1971). Furthermore, I used a strain (KP1294) where the conversion of guanine nucleotides to IMP (and hence to adenine nucleotides) is prevented due to a guaC mutation, as well as strain K P1474, which carries the leaky guaB235 mutation. The results are collected in Table 2.

The data clearly demonstrate that purine nucleotides play an important role in the regulation of the synthesis of pyrimidine biosynthetic enzymes in $S$. typhimurium. As exemplified for dihydroorotase in Fig. 3, the specific activity of this enzyme is linearly proportional to the intracellular concentration of GTP and inversely correlated with the ATP pool under these conditions, where the pyrimidine nucleotide pools remained relatively constant. Very similar curves are obtained when the specific activity of dihydroorotate dehydrogenase (of Table 2) is plotted against the pools of the individual nucleoside triphosphates (not shown). In contrast, the levels of aspartate transcarbamoylase or orotate phosphoribosyltransferase are high when the GTP pool is low and vice versa.

\section{Identification of the purine nucleotide effector as a guanine nucleotide}

In the experiments described above an inverse correlation between the ATP and GTP pools was always seen. To break this correlation, cultures of a gua $\mathrm{A}$ and a $\mathrm{guaB}$ mutant were allowed to exhaust a limiting supply of guanine (Fig. 4). The GTP pool fell abruptly following the break in 


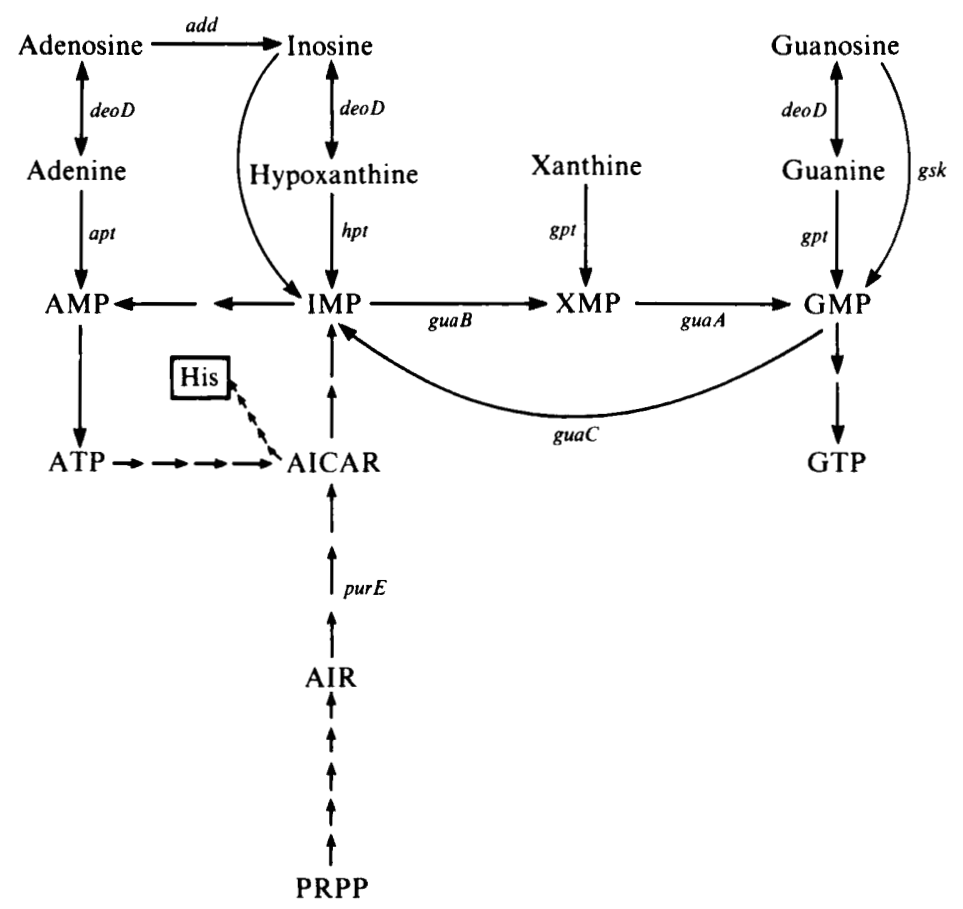

Fig. 2. Pathways for the biosynthesis and interconversion of purine nucleotides in S. typhimurium. The enzymes are identified by the corresponding gene symbols as follows: apt, adenine phosphoribosyltransferase (EC 2.4.2.7); deoD, purine-nucleoside phosphorylase (EC 2.4.2.1); gpt, guanine phosphoribosyltransferase (EC 2.4.2.-); gsk, guanosine kinase (2.7.1.-); guaA, GMP synthase (EC 6.3.4.1); guaB, IMP dehydrogenase (EC 1.1.1.205); guaC, GMP reductase (EC 1.6.6.8); purE, phosphoribosylaminoimidazole carboxylase (EC 4.1.1.21); pur $F$, amidophosphoribosyitransferase (EC 2.4.2.14); hpt, hypoxanthine phosphoribosyltransferase (EC 2.4.2.8). Other abbreviations: AIR, phosphoribosyl-5-aminoimidazole; AICAR, phosphoribosyl-5-amino-4-imidazolecarboxamide.

Table 2. Pools of nucleoside triphosphates and levels of pyrimidine biosynthetic enzymes in strains of S. typhimurium with defects in purine biosynthesis or interconversion

\begin{tabular}{|c|c|c|c|c|c|c|c|c|c|c|}
\hline \multirow{3}{*}{$\begin{array}{l}\text { Strain } \\
\text { (and } \\
\text { relevant } \\
\text { mutations) }\end{array}$} & \multirow{3}{*}{$\begin{array}{l}\text { Purine* } \\
(0.1 \mathrm{~mm})\end{array}$} & \multirow{2}{*}{\multicolumn{4}{|c|}{$\begin{array}{c}\text { Pool of: } \\
{\left[\mu \mathrm{mol}(\mathrm{g} \text { dry weight })^{-1}\right]}\end{array}$}} & \multicolumn{5}{|c|}{$\begin{array}{l}\text { Specific activity of } \dagger \text { : } \\
\text { [units }(\mathrm{mg} \text { protein })^{-1} \text { ] }\end{array}$} \\
\hline & & & & & & \multirow{2}{*}{$\begin{array}{l}\text { ATCase } \\
(\text { pyrBI) }\end{array}$} & \multirow{2}{*}{$\begin{array}{c}\text { DHOase } \\
(\text { pyrC })\end{array}$} & \multirow{2}{*}{$\begin{array}{l}\text { DHOox } \\
(\text { pyrD })\end{array}$} & \multirow{2}{*}{$\begin{array}{l}\text { OPRTase } \\
\quad(\text { pyrE })\end{array}$} & \multirow{2}{*}{$\begin{array}{l}\text { G-6-P } \\
\text { dehyd }\end{array}$} \\
\hline & & GTP & ATP & CTP & UTP & & & & & \\
\hline $\begin{array}{l}\text { KP1001 } \\
\text { (wt) }\end{array}$ & - & $2 \cdot 6$ & $5 \cdot 5$ & $1 \cdot 1$ & 1.4 & 37 & 88 & 29 & 50 & ND \\
\hline $\begin{array}{r}\text { KP1535 } \\
(\text { purE })\end{array}$ & $\begin{array}{l}\mathrm{Ad} \\
\mathrm{Hx} \\
\mathrm{Gu}\end{array}$ & $\begin{array}{l}1 \cdot 1 \\
3 \cdot 6 \\
4 \cdot 3\end{array}$ & $\begin{array}{r}12 \cdot 7 \\
7 \cdot 5 \\
4 \cdot 3\end{array}$ & $\begin{array}{l}0.8 \\
1.4 \\
1.4\end{array}$ & $\begin{array}{l}1.6 \\
1.7 \\
1.8\end{array}$ & $\begin{array}{l}87 \\
55 \\
20\end{array}$ & $\begin{array}{r}35 \\
90 \\
127\end{array}$ & $\begin{array}{l}13 \\
40 \\
44\end{array}$ & $\begin{array}{r}160 \\
60 \\
33\end{array}$ & $\begin{array}{l}233 \\
292 \\
301\end{array}$ \\
\hline $\begin{array}{l}\text { KP1548 } \\
\text { (purE deoD) }\end{array}$ & $\begin{array}{l}\mathrm{Ad} \\
\mathrm{Hx} \\
\mathrm{Gu}\end{array}$ & $\begin{array}{l}0 \cdot 3 \\
2 \cdot 7 \\
3 \cdot 1\end{array}$ & $\begin{array}{r}14 \cdot 1 \\
5 \cdot 4 \\
2.6\end{array}$ & $\begin{array}{l}0.8 \\
1.1 \\
1.2\end{array}$ & $\begin{array}{l}1 \cdot 1 \\
1 \cdot 1 \\
1 \cdot 4\end{array}$ & $\begin{array}{r}157 \\
45 \\
16\end{array}$ & $\begin{array}{l}12 \\
93 \\
93\end{array}$ & $\begin{array}{l}10 \\
35 \\
43\end{array}$ & $\begin{array}{r}246 \\
52 \\
58\end{array}$ & $\begin{array}{l}\text { ND } \\
333 \\
292\end{array}$ \\
\hline $\begin{array}{r}\mathrm{KP} 1294 \\
(\text { guaC })\end{array}$ & $\overline{\mathrm{Gu}}+\mathrm{GR}$ & $\begin{array}{l}3 \cdot 3 \\
5 \cdot 0\end{array}$ & $\begin{array}{l}6 \cdot 5 \\
2 \cdot 9\end{array}$ & $\begin{array}{l}1.4 \\
1.5\end{array}$ & $\begin{array}{l}2 \cdot 1 \\
1 \cdot 8\end{array}$ & $\begin{array}{l}24 \\
20\end{array}$ & $\begin{array}{l}122 \\
163\end{array}$ & $\begin{array}{l}54 \\
67\end{array}$ & $\begin{array}{l}43 \\
36\end{array}$ & $\begin{array}{l}239 \\
328\end{array}$ \\
\hline $\begin{array}{r}\text { KP } 1474 \\
(g u a B)\end{array}$ & $\overline{G u}$ & $\begin{array}{l}0.6 \\
4 \cdot 8\end{array}$ & $\begin{array}{r}14 \cdot 1 \\
5 \cdot 9\end{array}$ & $\begin{array}{l}1.0 \\
1.9\end{array}$ & $\begin{array}{l}1 \cdot 8 \\
2 \cdot 1\end{array}$ & $\begin{array}{r}807 \\
70\end{array}$ & $\begin{array}{r}21 \\
141\end{array}$ & $\begin{array}{l}15 \\
58\end{array}$ & $\begin{array}{r}648 \\
80\end{array}$ & $\begin{array}{l}204 \\
372\end{array}$ \\
\hline
\end{tabular}

ND, Not determined.

* Purines: Ad, adenine; Hx, hypoxanthine; Gu, guanine; GR, guanosine.

† Enzymes: ATCase, aspartate transcarbamoylase; DHOase, dihydroorotase; DHOox, dihydroorotate dehydrogenase; OPR Tase, orotate phosphoribosyltransferase; G-6-P dehyd, glucose-6-phosphate dehydrogenase. 


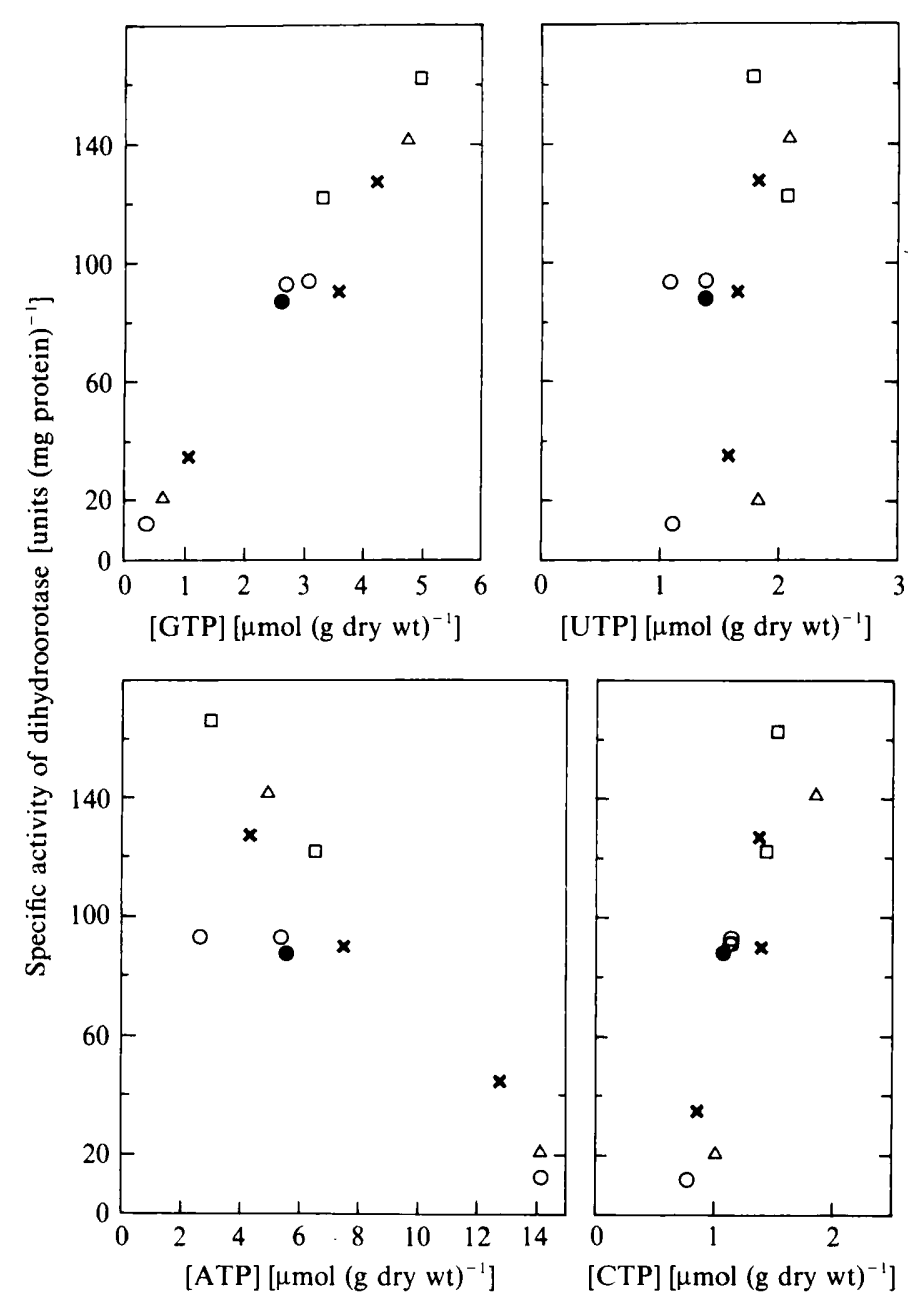

Fig. 3. Specific activity of dihydroorotase as a function of individual nucleoside triphosphate pools. Points obtained with different strains are shown with different symbols: KP1001 (O), KP1535 ( $\times$ ),

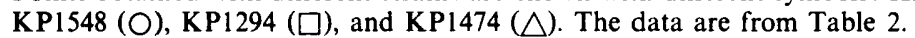

the growth curves for both strains, whereas the CTP and the UTP pools remained unchanged or increased slightly (Fig. 4). However, the two strains behaved differently with respect to ATP. The ATP pool of KP1476 ( $\mathrm{guaB}$ ) began to accumulate immediately after the exhaustion of guanine (Fig. $4 c$ ) while the ATP pool of strain KP1489 (guaA) decreased initially and only later began to increase (Fig. $4 d$ ). In both strains the levels of aspartate transcarbamoylase and orotate phosphoribosyltransferase increased considerably, while the levels of dihydroorotase and dihydroorotate dehydrogenase remained constant or decreased slightly (Fig. $4 a, b$ ). Thus, these data show that a guanine nucleotide (GTP, GDP or GMP) rather than an adenine nucleotide plays a role as effector of $p y r B I$ and $p y r E$ expression. IMP and XMP have no effect since a very high pool of IMP accumulated in KP1476 (guaB) and a very high XMP pool accumulated in KP1489 (guaA) during guanine starvation (not shown). The data are not as conclusive for $p y r C$ and $p y r D$ expression as they are for $p y r B I$ and $p y r E$, since repression of the synthesis of dihydroorotase and dihydroorotate dehydrogenase requires bacterial growth in order to be reflected in the enzyme levels.

Turnbough (1983) observed that the accumulation of ppGpp, induced by partial amino acid starvation, prevented derepression of aspartate transcarbamoylase synthesis in Escherichia coli, 

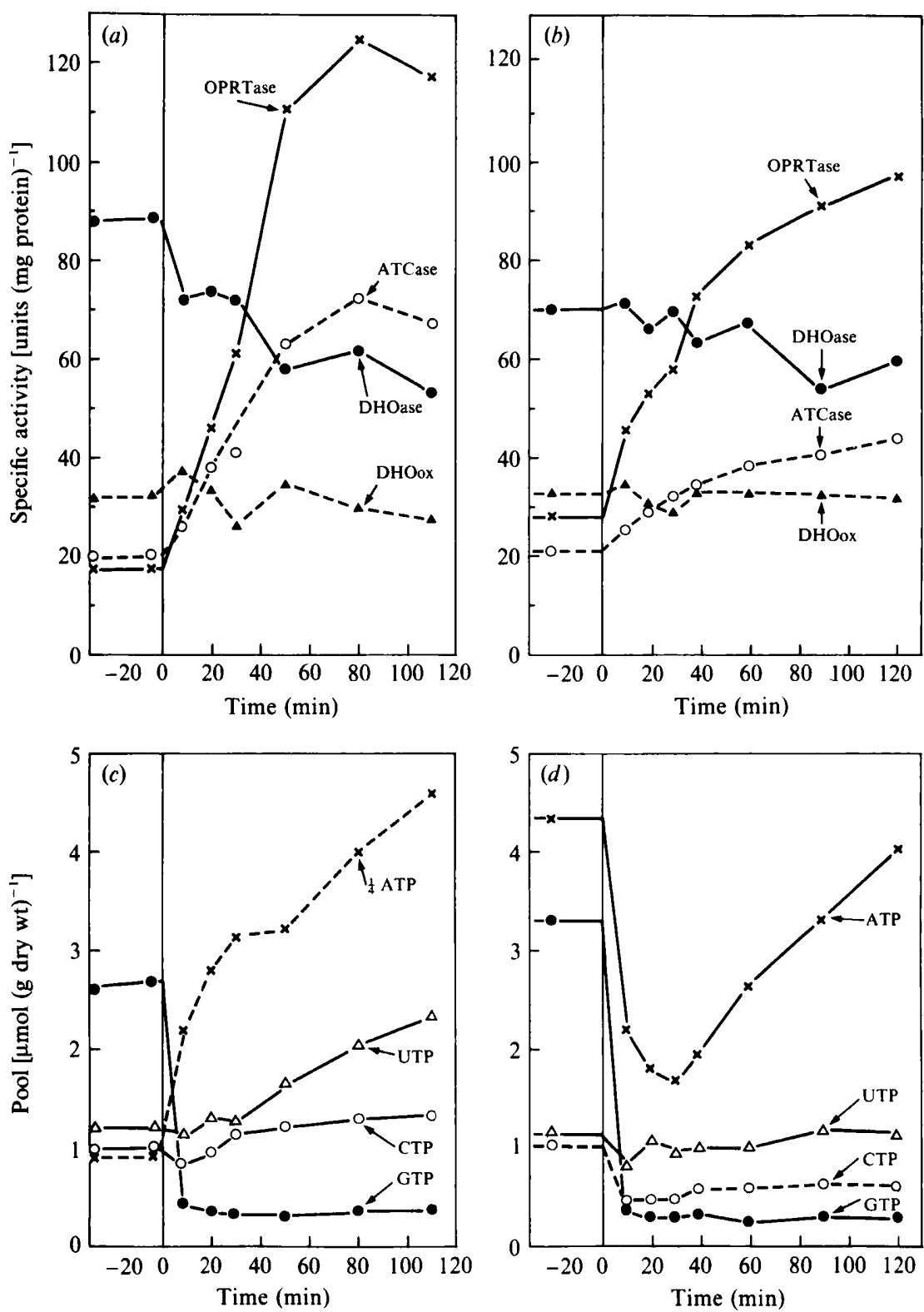

Fig. 4. Pyrimidine nucleotide biosynthetic enzymes and nucleoside triphosphate pools as $\mathbf{s}$ function of time after onset of guanine starvation of a guaB strain (KP1476; $a$ and $c$ ) and a guaA strain (KP1489; $b$ and $d)$. The cells were grown in a minimal medium supplemented with adenine $\left(15 \mu \mathrm{g} \mathrm{ml}^{-1}\right)$ and guanine $\left(6 \mu \mathrm{g} \mathrm{ml}^{-1}\right)$ and allowed to exhaust the guanine supply (time equals zero). At various times, samples were withdrawn for determination of nucleotide pools and pyrimidine nucleotide biosynthetic enzymes. In (c) the ATP pool is depicted as one-quarter of its actual size.

and similarly, a repressive effect of ppGpp on car $A B$ expression was noticed by Bouvier $e t$ al. (1984). However, the concentration of ppGpp was considered unlikely as the primary cause of the phenomena observed here, because it appeared low $\left[\leqslant 0 \cdot 1 \mu \mathrm{mol}(\mathrm{g} \text { dry weight })^{-1}\right]$ and constant in all experiments. This was judged by inspection of the autoradiograms. The magic spot (ppGpp) could easily be seen in these pictures. However, as it migrated at a position close to the origin where background is high and variable it was unreliable to determine the content of 
Table 3. Pools of nucleoside triphosphates and levels of pyrimidine biosynthetic enzymes in strains of S. typhimurium with defects in either purine or pyrimidine interconversion

The background for all experiments was that of KP1469 (cdd-9 cod-8 deoD201 udp-11).

\begin{tabular}{|c|c|c|c|c|c|c|c|c|c|c|}
\hline \multirow{3}{*}{$\begin{array}{l}\text { Strain } \\
\text { (and } \\
\text { relevant } \\
\text { mutations) }\end{array}$} & \multirow{3}{*}{$\begin{array}{l}\text { Addn* } \\
(0 \cdot 1 \mathrm{mM})\end{array}$} & \multicolumn{4}{|c|}{$\begin{array}{c}\text { Pool of: } \\
{\left[\mu \mathrm{mol}(\mathrm{g} \text { dry weight })^{-1}\right]}\end{array}$} & \multicolumn{5}{|c|}{$\begin{array}{l}\text { Specific activity of } \$ \text { : } \\
\text { [units (mg protein })^{-1} \text { ] }\end{array}$} \\
\hline & & & & & & CPSase & ATCase & DHOase & DHOox & OPRTase \\
\hline & & GIP & A1P & $\operatorname{cis}$ & UTP & $(p y r A)$ & (pyrBI) & (pyrc) & $(p y r D)$ & \\
\hline $\begin{array}{l}\text { KP1723 } \\
(\text { pyrH1631 } \\
\text { guaB235) }\end{array}$ & $\begin{array}{l}- \\
\text { CR } \\
\text { Ura } \\
\text { Gu } \\
\text { Gu, CR }\end{array}$ & $\begin{array}{l}0.59 \\
0.57 \\
0.68 \\
3.53 \\
3.60\end{array}$ & $\begin{array}{l}8.45 \\
7 \cdot 89 \\
8 \cdot 39 \\
3.45 \\
3 \cdot 42\end{array}$ & $\begin{array}{l}0.48 \\
1.92 \\
0.48 \\
0.95 \\
7 \cdot 0\end{array}$ & $\begin{array}{l}0.55 \\
0.52 \\
0.54 \\
0.60 \\
0.28\end{array}$ & $\begin{array}{l}44 \\
27 \\
42 \\
48 \\
61\end{array}$ & $\begin{array}{r}1860 \\
1955 \\
2411 \\
826 \\
2702\end{array}$ & $\begin{array}{l}45 \\
14 \\
46 \\
74 \\
28\end{array}$ & $\begin{array}{r}50 \\
25 \\
55 \\
126 \\
74\end{array}$ & $\begin{array}{l}826 \\
702 \\
879 \\
420 \\
518\end{array}$ \\
\hline $\begin{array}{l}\text { KP1722 } \\
\quad(\text { guaB235) }\end{array}$ & $\begin{array}{l}- \\
\text { CR } \\
\text { Ura } \\
\text { Gu } \\
\text { Gu, CR } \\
\text { Gu, Ura }\end{array}$ & $\begin{array}{l}0 \cdot 36 \\
0 \cdot 30 \\
0 \cdot 27 \\
2 \cdot 67 \\
2 \cdot 25 \\
2 \cdot 26\end{array}$ & $\begin{array}{r}9.78 \\
9.80 \\
10 \cdot 27 \\
4 \cdot 17 \\
3 \cdot 37 \\
4.27\end{array}$ & $\begin{array}{l}0.63 \\
0 \cdot 78 \\
0 \cdot 61 \\
1 \cdot 12 \\
2 \cdot 10 \\
1.56\end{array}$ & $\begin{array}{l}1 \cdot 24 \\
1.20 \\
1.48 \\
1.24 \\
1 \cdot 16 \\
1 \cdot 67\end{array}$ & $\begin{array}{r}9 \\
7 \\
5 \\
18 \\
15 \\
5\end{array}$ & $\begin{array}{r}134 \\
184 \\
104 \\
33 \\
28 \\
17\end{array}$ & $\begin{array}{l}21 \\
17 \\
15 \\
65 \\
32 \\
43\end{array}$ & $\begin{array}{r}13 \\
9 \\
16 \\
78 \\
34 \\
33\end{array}$ & $\begin{array}{r}413 \\
454 \\
327 \\
38 \\
34 \\
11\end{array}$ \\
\hline $\begin{array}{l}\text { KP1725 } \\
(\text { pyrH1631) }\end{array}$ & $\overline{\mathrm{CR}}$ & $\begin{array}{l}1.62 \\
2 \cdot 78\end{array}$ & $\begin{array}{l}3 \cdot 12 \\
4 \cdot 67\end{array}$ & $\begin{array}{l}0 \cdot 45 \\
4 \cdot 32\end{array}$ & $\begin{array}{l}0.43 \\
0.23\end{array}$ & $\begin{array}{l}40 \\
40\end{array}$ & $\begin{array}{r}992 \\
2662\end{array}$ & $\begin{array}{l}73 \\
29\end{array}$ & $\begin{array}{r}133 \\
69\end{array}$ & $\begin{array}{l}401 \\
439\end{array}$ \\
\hline KP1724 & $\begin{array}{l}- \\
\text { CR } \\
\text { Ura }\end{array}$ & $\begin{array}{l}1 \cdot 67 \\
1 \cdot 37 \\
1 \cdot 61\end{array}$ & $\begin{array}{l}4 \cdot 08 \\
3 \cdot 57 \\
4 \cdot 51\end{array}$ & $\begin{array}{l}0 \cdot 87 \\
1 \cdot 40 \\
1 \cdot 16\end{array}$ & $\begin{array}{l}1.49 \\
1.35 \\
1.63\end{array}$ & $\begin{array}{r}15 \\
14 \\
5\end{array}$ & $\begin{array}{l}34 \\
52 \\
11\end{array}$ & $\begin{array}{l}58 \\
37 \\
46\end{array}$ & $\begin{array}{l}39 \\
23 \\
25\end{array}$ & $\begin{array}{l}37 \\
26 \\
13\end{array}$ \\
\hline
\end{tabular}

* Additions: -, none; CR, cytidine; Ura, uracil; Gu, guanine.

† Enzymes: CPSase, carbamoylphosphate synthase; ATCase, aspartate transcarbamoylase; DHOase, dihydroorotase; DHOox, dihydroorotate dehydrogenase; OPRTase, orotate phosphoribosyltransferase. The level of glucose-6-phosphate dehydrogenase was measured in all experiments; the lowest value was 398 units mg $^{-1}$ and the highest value was 550 units $\mathrm{mg}^{-1}$.

radioactivity in the spot. Further evidence that $\mathrm{ppGpp}$ plays at most a minor role under these conditions stems from the fact that guaB mutants of $E$. coli which are relaxed $(\mathrm{rel} A)$ behave like the guaB mutants in the stringent $\left(\mathrm{relA}^{+}\right)$Salmonella strain used herein with regard to $\mathrm{pyr} E$ expression (Poulsen \& Jensen, 1987).

\section{Changing the pools of both purine and pyrimidine nucleotides}

For the purpose of creating changes in both the pyrimidine and purine nucleotide pools a set of strains was constructed by introducing $g u a B$ and $p y r H$ alleles in the background of KP1469 (Table 1). One strain (KP1724) contained none of the mutations. Another strain (KP1722) carried the leaky mutation guaB235. The third strain (KP1725) harboured a leaky mutation, pyrH1631, and grew exponentially with low pools of UTP. In the fourth strain (KP1723) both these mutations, guaB235 and pyrH1631, were present.

This set of bacteria was cultivated either in unsupplemented minimal medium or in a medium containing guanine, cytidine or uracil. The cells were harvested and the content of nucleoside triphosphates and pyrimidine biosynthetic enzymes was determined. In these experiments the cultures were grown in the same batch of medium to minimize experimental uncertainty. The results are collected in Table 3.

Since each pyr gene shows its own characteristic regulatory pattern it seems most convenient to discuss the genes individually.

\section{Regulation of pyrC expression}

According to Schwartz \& Neuhard (1975) the level of dihydroorotase, encoded by $p y r C$, is negatively correlated with the intracellular concentration of CTP. The data in Fig. 3 and Table 2 indicated that the level of this enzyme is close to being proportional to the GTP pool. Thus it seemed reasonable to plot the levels of dihydroorotase, taken from Table 3, as a function of either the GTP pool or the CTP pool (Fig. $5 a, b)$. It appears that both of these plots are quite 


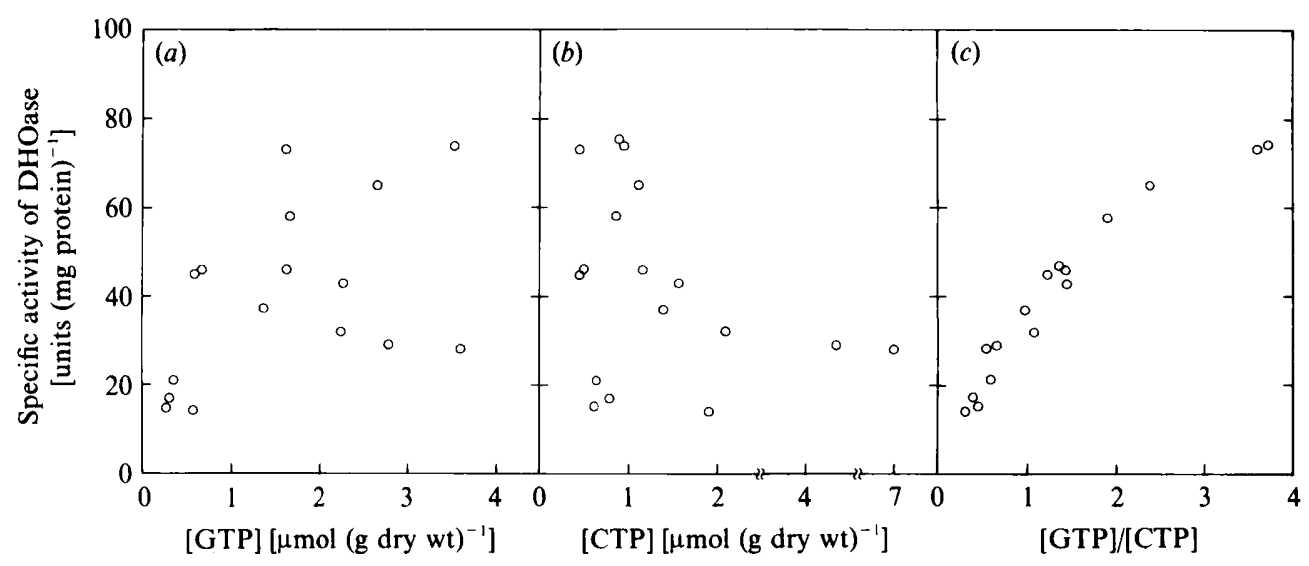

Fig. 5. Specific activity of dihydroorotase as a function of the GTP pool (a), the CTP pool $(b)$, and the $[\mathrm{GTP}] /[\mathrm{CTP}]$ pools ratio $(c)$. Data from Table 3.

scattered. However, when the enzyme levels are depicted versus the pools ratio ([GTP]/[CTP]) the data points meet nicely on a curve with very little scatter (Fig. 5c). This indicates that the pools of GTP and CTP account for the majority of the variation in pyrC gene expression observed under these conditions. Accordingly, GTP stimulates pyrC expression, while CTP inhibits it.

Neuhard et al. (1986) and Kelln \& Neuhard (1988) have found that $p y r C$ gene expression in $S$. typhimurium is regulated primarily at the translation level. They found that the pyrC mRNA chain can form a secondary structure around the ribosome-binding site. Accordingly, the authors anticipated the existence of a regulatory protein which may bind to the mRNA chain and stabilize the conformation which inhibits protein synthesis (Kelln \& Neuhard, 1988). If this explanation is valid the data in this paper suggest that GTP competes with CTP and makes the 'open' pyrC mRNA conformation favourable. Thereby a high intracellular GTP concentration promotes translation of the $p y r C$ cistron even at high CTP pools.

\section{Regulation of pyrD gene expression}

The level of dihydroorotate dehydrogenase was previously found to be negatively correlated with the intracellular concentration of CTP, and to change in parallel with pyrC gene expression (Schwartz \& Neuhard, 1975). According to the data in Table 2, dihydroorotate dehydrogenase, like dihydroorotase, is synthesized in proportion to the GTP pool when no deliberate changes are made in the pools of pyrimidine nucleotides. Thus it seemed reasonable to assume that the level of this enzyme would be explained by the [GTP]/[CTP] pools ratio as seen for dihydroorotase (Fig. 5). However, this turned out not to be the case: when the enzyme levels were depicted as a function of the $[\mathrm{GTP}] /[\mathrm{CTP}]$ ratio all points obtained by analysis of cultures grown with low UTP pools fell above the curve defined by the other points (not shown). Instead I have plotted the levels of dihydroorotate dehydrogenase in Table 3 against the GTP pool, the UTP pool, or the [GTP]/[UTP] ratio (Fig. 6). The data points in the first two first figures (6a and $b$ ) are scattered. However, in the last figure $(6 c)$ the data points meet on two curves: the upper curve is seen for the points obtained from cells grown with low or normal CTP pools, while the lower curve is seen for the points obtained from cultures grown in the presence of cytidine, which causes a very high concentration of CTP to accumulate in the cells. Thus, it appears that the synthesis of dihydroorotate dehydrogenase is influenced by three nucleotides: CTP and UTP inhibit pyrD expression, while GTP stimulates it.

As for the pyrC gene, the ribosome-binding sites of the pyrD gene of E. coli (Larsen \& Jensen, 1985 ) and $S$. typhimurium (R. Kelln, personal communication) are preceded by secondary structures in the mRNA chain. Therefore it is possible that the CTP and GTP effects on the 


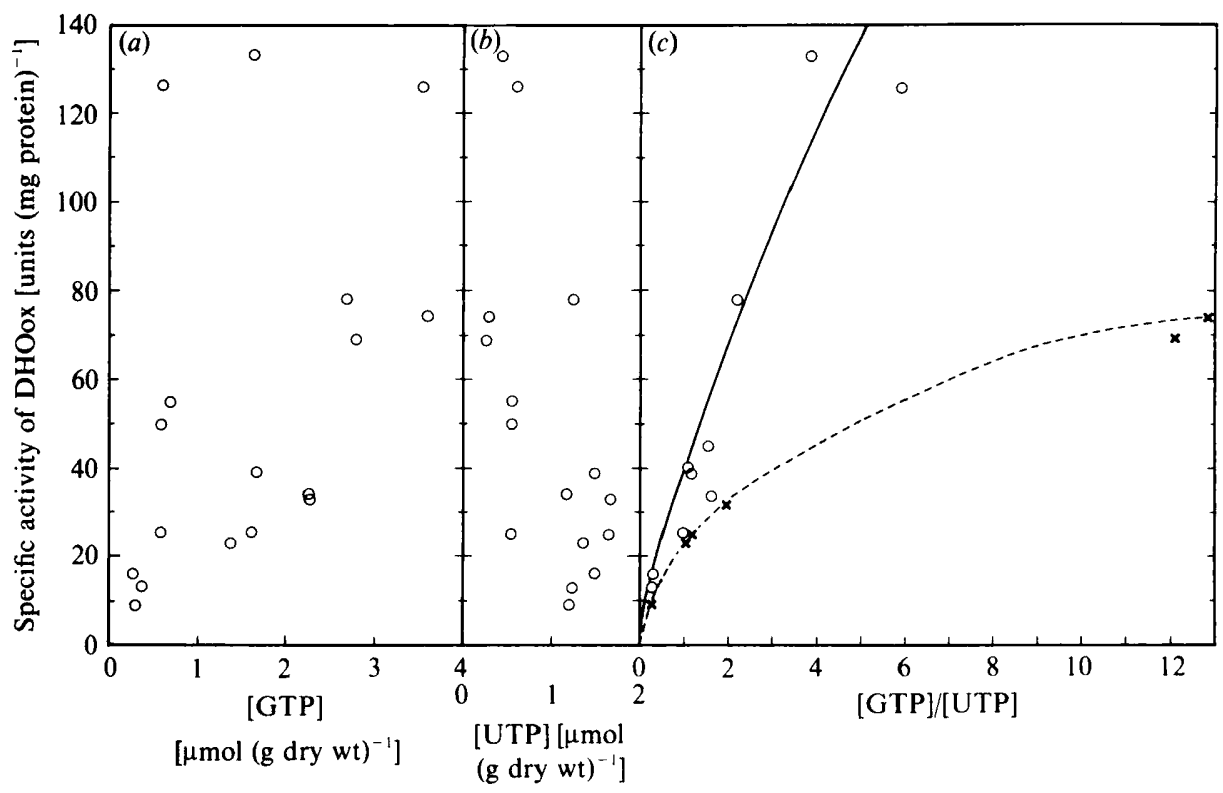

Fig. 6. Specific activity of dihydroorotate dehydrogenase as a function of the GTP pool $(a)$, the UTP pool $(b)$, and the $[\mathrm{GTP}] /[\mathrm{UTP}]$ pools ratio $(c)$. Data from Table 3.

pyrD gene are exerted by a mechanism involving the mRNA translation efficiency, as for $p y r C$. However, in addition pyr $D$ gene expression (in $E$. coli) is regulated at the level of transcription and sensitive to changes in the UTP pool (Jensen et al., 1984).

\section{Regulation of pyrA gene expression}

The synthesis of carbamoylphosphate synthase, which participates in the synthesis both of pyrimidine nucleotides and of arginine (Fig. 1), appears to be stimulated by a guanine nucleotide. The UTP pool as well as the CTP pool seems to repress the synthesis of this enzyme (Table 3). These pyrimidine effects are in agreement with recent results of Kilstrup et al. (1988).

\section{Control of pyrBI and pyrE gene expression}

Expression of pyrBI and pyrE is influenced by the pools of UTP and GTP, both causing repression (Tables 2 and 3). However, neither the individual pools nor any ratio between these satisfactorily correlate with the enzyme levels (Table 3 ).

The pyrBI and pyrE genes encode the two subunits of aspartate transcarbamoylase and the subunit of orotate phosphoribosyltransferase, respectively. The expression level of both genes is regulated by transcription attenuation and is inversely correlated with the pool of UTP (Turnbough et al., 1983; Roland et al., 1985; Clemmesen et al., 1985; Michaels et al., 1987; Poulsen et al., 1983, 1984; Bonekamp et al., 1984; Neuhard et al., 1985; Jensen et al., 1986a; Poulsen \& Jensen, 1987). Since attenuation is regulated by the mRNA chain elongation rate, rather than by the free UTP pool (Jensen et al., 1982, 1986 b), it may not be surprising that pyrBI and $p y r E$ expression also responds to changes in the intracellular concentration of GTP. The $K_{\mathrm{m}}$ values for the interaction between the elongating RNA polymerase and both UTP and GTP are high relative to the intracellular concentrations of these compounds, while the intracellular concentrations of ATP and CTP are substantially above the concentrations needed for halfmaximal saturation of RNA polymerase (Kingston et al., 1981; Jensen et al., 1986b). Therefore it is reasonable that the UTP and GTP pools, rather than the ATP and CTP pools, are of importance for $p y r B I$ and $p y r E$ expression. 


\section{Expression of the pyrF gene}

The levels of OMP decarboxylase were not measured in these experiments. However, from previous studies (Jensen, 1979) it is known that the activity of this enzyme is high in a leaky guaB mutant grown with a low pool of GTP. Therefore, a guanine nucleotide appears to inhibit pyr $F$ gene expression.

\section{Conclusion}

The present paper is rather descriptive and does not provide any clues to the understanding of pyr gene control at the molecular and mechanistic level. However, the data show that the pyr genes are controlled in a highly complex manner by the nucleotide pools in $S$. typhimurium and that each gene shows its own characteristic regulatory pattern. Hopefully, the data may be useful in the design of future experiments aimed at gaining a complete understanding of the control of pyrimidine nucleotide biosynthesis at the molecular level.

I appreciate the technical help of Lise Schack and thank André Piérard and Jan Neuhard for suggestions to improve the manuscript. The work received financial support from the Danish Natural Science Foundation.

\section{REFERENCES}

Abdelal, A. T. H. \& Ingraham, J. L. (1975). Carbamylphosphate synthetase from Salmonella typhimurium. Journal of Biological Chemistry 250 , 4410-4417.

Bonekamp, F., Clemmesen, K., Karlström, O. \& JENSEN, K. F. (1984). Mechanism of UTP-modulated attenuation at the pyrE gene of Escherichia coli: an example of operon polarity control through the coupling between translation and transcription. EMBO Journal 3, 2857-2861.

Bouvier, J., Patte, J.-C. \& Stragier, P. (1984), Multiple regulatory signals in the control region of the Escherichia coli carAB operon. Proceedings of the National Academy of Sciences of the United States of America 81, 4139-4143.

Clark, D. J. \& Maaløe, O. (1967). DNA replication and the division cycle of Escherichia coli. Journal of Molecular Biology 23, 99-112.

Clemmesen, K., Bonekamp, F., Karlström, O. \& JENSEN, K. F. (1985). Role of translation in the UTPmodulated attenuation at the pyrBI gene of Escherichia coli. Molecular and General Genetics 201, 247251.

EdLIN, G. \& MaAløe, O. (1966). Synthesis and breakdown of mRNA without protein synthesis. Journal of Molecular Biology 15, 428-434.

Gerhart, J. C. \& Pardee, A. B. (1962). The enzymology of control of feedback inhibition. Journal of Biological Chemistry 237, 891-896.

HOFFMEYER, J. \& NeUHARD, J. (1971). Metabolism of exogenous purine bases and nucleosides by Salmonella typhimurium. Journal of Bacteriology 106, 14-24.

JENSEN, K. F. (1979). Apparent involvement of purines in the control of expression of Salmonella typhimurium pyr genes: analysis of a leaky guaB mutant resistant to pyrimidine analogs. Journal of Bacteriology 138, 731-738.

Jensen, K. F., Houlberg, U. \& NygaARd, P. (1979) Thin-layer chromatographic methods to isolate ${ }^{32}$ P-labeled 5-phosphoribosyl- $\alpha$-1-pyrophosphate (PRPP): determination of cellular PRPP pools and assay of PRPP synthetase. Analytical Biochemistry 98, 254-263.
Jensen, K. F., Neuhard, J. \& Schack, L. (1982). RNA polymerase involvement in the regulation of Salmonella typhimurium pyr genes. Isolation of a fluorouracil-resistant mutant with high, constitutive expression of $p y r B$ and $p y r E$ genes due to a mutation in rpoBC. EMBO Journal 1, 69-74.

Jensen, K. F., LARSEN, J. N., SChaCK, L. \& Sivertsen, A. (1984). Studies on the structure and expression of Escherichia coli pyrC, pyrD and pyrF using the cloned genes. European Journal of Biochemistry 140, 343352.

Jensen, K. F., Bonekamp, F. \& Poulsen, P. (1986a). Attenuation at nucleotide biosynthetic genes and amino acid biosynthetic operons of Escherichia coli. Trends in Biochemical Sciences 11, 362-365.

Jensen, K. F., Fast, R., Karlström, O. \& Larsen, J. N. $(1986 b)$. Association of RNA polymerase having increased $K_{\mathrm{m}}$ for ATP and UTP with hyperexpression of the pyrB and pyrE genes of Salmonella typhimurium. Journal of Bacteriology 166, 857-865.

Kelln, R. A. \& Neuhard, J. (1988). Regulation of pyrC expression in Salmonella typhimurium: identification of a regulatory region. Molecular and General Genetics 212, 287-294.

Kelln, R. A., Kinahan, J. J., Foltermann, K. F. \& O'Donovan, J. R. (1975). Pyrimidine biosynthetic enzymes of Salmonella typhimurium, repressed by growth in the presence of cytidine. Journal of Bacteriology 124, 764-774.

Kilstrup, M., LU, C.-D., Abdelal, A. \& Neuhard, J. (1988). Nucleotide sequence of the $\operatorname{car} A$ gene and regulation of the carAB operon in Salmonella typhimurium. European Journal of Biochemistry 175, 587-593.

Kingston, R. E., Nierman, W. C. \& Chamberlin, M (1981). A direct effect of guanosine tetraphosphate on pausing of Escherichia coli RNA polymerase during RNA chain elongation. Journal of Biological Chemistry 256, 2787-2797.

KORNBERG, A. \& HORECKER, B. L. (1955). Glucose-6phosphate dehydrogenase. Methods in Enzymology 1, 323-326. 
LARsen, J. N. \& Jensen, K. F. (1985). Nucleotide sequence of the pyrD gene of Escherichia coli and characterization of the flavoprotein dihydroorotate dehydrogenase. European Journal of Biochemistry 151, 59-65.

Michaels, G., Kelln, R. A. \& Narang, F. E. (1987). Cloning, nucleotide sequence and expression of the pyrBI operon of Salmonella typhimurium. European Journal of Biochemistry 166, 55-61.

MILlER, J. H. (1972). Experiments in Molecular Genetics. Cold Spring Harbor, NY: Cold Spring Harbor Laboratory.

Neuhard, J., Jensen, K. F. \& Stauning, E. (1982). Salmonella typhimurium mutants with altered expression of the pyrA gene due to changes in RNA polymerase. EMBO Journal 1, 1141-1149.

Neuhard, J., Stauning, E. \& Kelln, R. A. (1985). Cloning and characterization of the $p y r E$ gene and of pyrE: :Mud 1(Aplac) fusions from Salmonella typhimurium. European Journal of Biochemistry 146, 597603.

Neuhard, J., Kelln, R. A. \& Stauning, E. (1986). Cloning and characterization of the Salmonella typhimurium pyrC gene encoding dihydroorotase. European Journal of Biochemistry 157, 335-342.

Poulsen, P. \& JeNSEN, K. F. (1987). Effect of UTP and GTP pools on attenuation at the pyrE gene of Escherichia coli. Molecular and General Genetics 208, 152-158.
Poulsen, P., Jensen, K. F., Valentin-Hansen, P., Carlsson, P. \& Lundberg, L. G. (1983). Nucleotide sequence of the Escherichia coli pyrE gene and of the DNA in front of the protein-coding region. European Journal of Biochemistry 135, 1783-1790.

Poulsen, P., Bonekamp, F. \& Jensen, K. F. (1984). Structure of the Escherichia coli pyrE operon and control of pyrE expression by a UTP-modulated intercistronic attenuation. EMBO Journal 3, 17831790.

Roland, K. L., Powell, F. E. \& Turnbough, C. L., $J_{R}$ (1985). Role of translation and attenuation in the control of pyrBI operon expression in Escherichia coli K-12. Journal of Bacteriology 163, 991-999.

SchwartZ, M. \& Neuhard, J. (1975). Control of expression of the pyr genes in Salmonella typhimurium: effects of variations in uridine and cytidine nucleotide pools. Journal of Bacteriology 121, 814822.

Turnbough, C. L., JR (1983). Regulation of Escherichia coli aspartate transcarbamylase synthesis by guanosine tetraphosphate and pyrimidine ribonucleoside triphosphates. Journal of Bacteriology 153, 998-1007.

Turnbough, C. L., JR, Hicks, H. L. \& Donahue, J. P. (1983). Attenuation control of pyrBI operon expression in Escherichia coli K12. Proceedings of the National Academy of Sciences of the United States of America 80, 368-372. 